Огляди літератури, оригінальні дослідження, погляд на проблему, випадок з практики, короткі повідомлення УДК 616-006(091):159.9

DOI 10.11603/1811-2471.2020.v.i1.11078

\title{
ГЕНДЕРНІ ОСОБЛИВОСТІ ПРОЯВУ КЛІНІКО-ПСИХОЛОГІЧНИХ ФЕНОМЕНІВ У ОНКОЛОГІЧНИХ ПАЦІЄНТІВ
}

\author{
ОТ. Г. Кривоніс ${ }^{1}$, І. В. Жулкевич ${ }^{2}$
}

${ }^{1}$ Вінницький національний медичний університет імені М. І. Пирогова

${ }^{2}$ Тернопільський начіональний медичний університет імені І. Я. Горбачевського МОз України

РЕЗЮМЕ. Онкологічне захворювання спричиняє значні зрушення у психічному функціонуванні пацієнтів, що проявляється як донозологічними психічними реакціями та феноменами, так і клінічно вираженими психічними розладами.

Мета - вивчити особливості прояву клініко-психологічних феноменів у онкологічних пацієнтів залежно від статі.

Матеріал і методи. На основі інформованої згоди у спеціалізованих медичних закладах м. Вінниці, що надають онкологічну допомогу, було обстежено 286 онкологічних пацієнтів, з них 174 жінки (ГЖ) та 114 чоловіків (ГЧ). Хворих досліджували на різних етапах перебігу онкопатолої̈, а саме, при першому зіткненні з захворюванням - 78 жінок та 51 чоловік та при поверненні хвороби - 96 осіб жіночої та 63 - чоловічої статі.

Результати. Структура клініко-психологічних феноменів у чоловіків та жінок була подібною та розподілялася наступним чином: феномен «поділу життя» (80,5 \% у ГЖ та 81,6 \% у ГЧ), «нового початку» (відповідно 79,3 \% та 78,1\%), «сортеру» (69,5 \% та 60,5 \%), «маятника» (39,1\% та 33,3\%), «екстерналізації» (22,4 \% та 24,6 \%), «децентралізації» (20,7 \% та 24,6 \%) та «індукції» (18,4 \% та 17,5 \%). У жінок виявлено схильність до більшої вибірковості у сприйнятті психотравмуючої інформації, змін у психоемоційному стані у зв'язку із онкологічним захворюванням, формування співзалежних стосунків, тоді як для чоловіків притаманним було застосування психологічних механізмів захисту, спрямованих на винесення джерела внутрішньої напруги назовні.

Прогресування онкологічного захворювання спричиняло зростання психічного напруження, песимізму щодо прогнозів лікування, підвищення селективності у сприйнятті інформації, деформації міжособистісних зв'язків, збільшення напруженості психологічних механізмів захисту.

Висновки. Вивчення клініко-психологічних феноменів у онкологічних пацієнтів має важливе значення для організації заходів медико-психологічної допомоги. Відмінності у психологічному стані хворих, що виникають на різних етапах розвитку хвороби та в залежності від статі, визначають основу для диференціювання медико-психологічних заходів.

КлючовІ СловА: клініко-психологічні феномени; онкологічні пацієнти; гендер; психологічна допомога; психоонкологія.

Вступ. Несприятливий перебіг онкопатології спричиняє розвиток широкого спектра порушень у психічній сфері - від психологічних реакцій до клінічно окреслених психічних розладів $[1,2]$. Про значну ураженість психічного здоров'я онкохворих свідчить поширеність психічних розладів афективного, невротичного та органічного характеру: депресивний розлад визначається у 9,6-25,6\% пацієнтів, тривожно-фобічні розлади у 8,6-20,4 \%, розлад адаптації до $70 \%$, психотичні стани - у 10-40 \% на термінальній стадії; органічні психічні розлади до $8 \%$ [3-5].

На психосоціальному рівні онкологічні захворювання проявляються зниженням якостя життя [6] та порушеннями професійного, сімейного життя, стигматизацією [7]. Часто у практиці онкологів зустрічаються випадки відмови від лікування, надмірна песимістичність, застосування хворими нетрадиційної медицини, що має негативні наслідки для пацієнта та у більшості випадків спричинено виразними порушеннями у психічній сфері. Саме тому одним із провідних завдань медико-психологічної допомоги $\epsilon$ психокорекція емоційної, когнітивної та поведінкової сфер, яка має на меті нормалізацію психічного стану та адаптацію до протипухлинного лікування [8].

У психоонкологічній практиці застосовують різноманітні психотерапевтичні напрямки - психоаналітичний, когнітивно-поведінковий, арт-терапевтичний та інші, які реалізують у формі індивідуальної та групової психотерапії [9-12].

Мета - вивчити особливості прояву клінікопсихологічних феноменів у онкологічних пацієнтів залежно від статі.

Матеріал і методи дослідження. На основі інформованої згоди у спеціалізованих медичних закладах м. Вінниці, що надають онкологічну допомогу, було обстежено 286 онкологічних пацієнтів, в тому числі174 жінки (ГЖ) та 114 чоловіків (ГЧ). Хворих обстежували на різних етапах перебігу онкопатолоії, а саме, при першому зіткненні з захворюванням - 78 жінок (ГЖ1) та 51 чоловік (ГЧ1), та при поверненні (рецидиві) захворювання - 96 осіб жіночої (ГЖ2) та 63 - чоловічої статі (ГЧ2). Вік пацієнтів був у діапазоні від 46 до 67 років [13]. Для діагностики особливостей проявів клініко-психологічних феноменів, що супроводжували перебіг онкологічного захворювання на 
Огляди літератури, оригінальні дослідження, поглядн різних етапах його перебігу, проводили напівструктуроване психологічне інтерв'ю з наступною якісною оцінкою отриманих даних.

Оцінку психологічного статусу пацієнтів з онкологічними захворюваннями визначали із застосуванням феноменології клініко-психологічних проявів у онкологічній практиці, до яких належать феномени «поділу життя», «сортера», «нового початку», «маятника», «екстерналізації психічної напруги», «психологічної індукції», «децентралізації» [14]:

- феномен «поділу життя» характеризував зміни у психоемоційному стані пацієнтів, що на психологічному рівні розділяли їх життя на до та після встановлення онкологічного діагнозу, який становив безпосередню загрозу для життя;

- феномен «сортеру» вказував на когнітивні механізми захисту у вигляді селективності сприйняття психотравмуючої інформації, шляхом витіснення, заперечення, викривлення негативних новин, пов'язаних із захворюванням;

- феномен «нового початку» визначав завершення етапу протипухлинного лікування і прояв- роблему, випадок з практики, короткі повідомлення лявся у позитивних очікуваннях щодо прогнозу, оптимізму стосовно подолання чи стабілізації захворювання;

- феномен «маятника» - коливання психоемоційного стану від «полюсу надії» до «полюсу розпачу» на фоні прогресування захворювання і змін у фізичному стані;

- феномен «екстерналізації психічної напруги» стосувався зменшення внутрішнього напруження за рахунок винесення психічної напруги назовні, а саме, списування погіршення стану на побічну дію препаратів, «невірно» вибрану тактику лікування, некомпетентність медперсоналу;

- феномен «індукції» відображав формування співзалежності у міжособистісній взаємодії;

- феномен "децентралізації» описувався через акцентування уваги на менш значимих проявах патології.

Результати й обговорення. У таблиці 1 представлено структуру клініко-психологічних феноменів в залежності від статі обстежених онкологічних пацієнтів.

Таблиця 1. Розподіл клініко-психологічних феноменів в залежності від гендерної приналежності, \%

\begin{tabular}{|c|c|c|}
\hline Феномени & Група жінок, n=174 & Група чоловіків, $\mathrm{n}=114$ \\
\hline Феномен «Поділу життя» & 80,5 & 81,6 \\
\hline Феномен «Сортера» & 69,5 & 60,5 \\
\hline Феномен «Нового початку» & 79,3 & 78,1 \\
\hline Феномен «Маятника» & 39,1 & 33,3 \\
\hline Феномен «Екстерналізації» & 22,4 & 24,6 \\
\hline Феномен «Індукції» & 18,4 & 17,5 \\
\hline Феномен «Децентралізації» & 20,7 & 24,6 \\
\hline
\end{tabular}

Структура клініко-психологічних феноменів у чоловіків та жінок була подібною та розподілилася наступним чином: феномен «поділу життя» (80,5 \% у ГЖ та 81,6 \% у ГЧ), «нового початку» (відповідно 79,3 \% та 78,1\%), «сортера» (69,5 \% та 60,5\%), «маятника» $(39,1 \%$ та 33,3 \%), «екстерналізації» (22,4 \% та 24,6 \%), «децентралізації» $(20,7 \%$ та $24,6 \%)$ та «індукції» $(18,4 \%$ та $17,5 \%)$. За рядом феноменів виявлено відмінності у ступені прояву залежно від статі, а саме, схильність жінок до відкидання несприятливої інформації щодо хвороби, коливань психоемоційного стану у зв'язку із онкологічним захворюванням, схильність до співзалежних стосунків, тоді як для чоловіків більш притаманним було застосування психологічних механізмів захисту, спрямованих на винесення джерела внутрішньої напруги назовні.

У таблиці 2 наведено розподіл клініко-психологічних феноменів, що виникають під час онкологічного захворювання, у жінок та чоловіків на різних етапах перебігу хвороби.

Таблиця 2. Структура клініко-психологічних феноменів на етапах лікувального процесу у онкологічних хворих, \%

\begin{tabular}{|l|c|c|c|c|}
\hline \multicolumn{1}{|c|}{ Феномени } & $\begin{array}{c}\text { Група жінок 1, } \\
\mathrm{n=78}\end{array}$ & $\begin{array}{c}\text { Група жінок 2, } \\
\mathrm{n=96}\end{array}$ & $\begin{array}{c}\text { Група чоловіків 1, } \\
\mathrm{n}=51\end{array}$ & $\begin{array}{c}\text { Група чоловіків 2, } \\
\mathrm{n=63}\end{array}$ \\
\hline Феномен «Поділу життя» & 100 & 64,6 & 100 & 66,7 \\
\hline Феномен «Сортера» & 64,1 & 74,0 & 52,9 & 66,7 \\
\hline Феномен «Нового початку» & 97,4 & 64,6 & 98,0 & 61,9 \\
\hline Феномен «Маятника» & 32,1 & 44,8 & 27,5 & 38,1 \\
\hline Феномен «Екстерналізації» & 17,9 & 26,0 & 17,6 & 30,2 \\
\hline Феномен «Індукції» & 14,1 & 21,9 & 11,8 & 22,2 \\
\hline Феномен «Децентралізації» & 16,7 & 24,0 & 19,6 & 28,6 \\
\hline
\end{tabular}


Огляди літератури, оригінальні дослідження, погляд на проблему, випадок з практики, короткі повідомлення

У структурі клініко-психологічних феноменів у онкохворих жінок на етапі первинного зіткнення із захворюванням (ГЖ1) провідну роль мали феномени «поділу життя» (100\%) та «нового початку» (100\%), менше - «сортера» $(64,1 \%)$ та «маятника» $(32,1 \%)$, прояви «екстерналізації» $(17,9 \%)$, «децентралізації» (16, \%) та «індукції» (14,1%) були представлені найменше.

Серед жінок з онкопатологією у випадку рецидиву захворювання (ГЖ2) феномени розподілилися наступним чином: домінували прояви «сортера» (74,0 \%), за ними слідували прояви «поділу життя» (64,6 \%) та «нового початку» (64,6 \%), менш представленими буви прояви «маятника» (44,8 \%), «екстерналізації» $(26,0$ \%), «децентралізації» $(24,0$ \%) та «індукції» $(21,9 \%)$.

У онкохворих чоловіків з ГЧ1 структура клінікопсихологічних феноменів була подібною до такої в жінок: провідними були прояви «поділу життя» (100 \%) та «нового початку» $(98,0 \%)$, за ними слідували «сортер» (52,9\%), «маятник» $(27,5$ \%), «децентралізація» (19,6\%), «екстерналізація» (17,6\%) та «індукція» (11,8 \%). При поверненні онкопатології у чоловіків розподіл психологічних феноменів був наступним: домінували прояви «поділу життя» $(66,7 \%)$, «сортера» $(66,7 \%)$ та «нового початку» (61,9 \%), менш вираженими у порядку зменшення були ознаки «маятника» $(38,1 \%)$, «екстерналізації» (30,2 \%), «децентралізації» (28,6 \%) та індукції (22,2 \%).

У результаті порівняння розподілу клінікопсихологічних феноменів у онкохворих в залежності від етапу перебігу захворювання виявлено зростання вибірковості за типом відкидання негативної інформації щодо хвороби як непереносимої і загрожуючої (феномен «сортера», 64,1% проти 74,0 \% у ГЖ та 52,9 \% проти $66,7 \%$ у ГЧ), посилення коливань психоемоційного стану (феномен «маятника», 32,1 \% проти 44,8 \% та відповідно 27,5 \% проти 38,1 \%), зростання песимістичного ставлення до прогнозу і можливостей подолання захворювання (феномен «нового початку», 97,4 \% проти 64,6 \% та 98,0 \% проти 61,9 \%) та по-

\section{ЛІТЕРАТУРА}

1. Білобривка Р. І. Свідомість між життям та смертю. Феноменолоґічний та гносеолоґічний аспект / P. І. Білобривка // Acta medica Leopoliensia. - 2013. T. 19, № 4. - C. 56-61.

2. García-Torres F. Anxiety in common situations of everyday life in breast cancer survivors / F. García-Torres, F. J. Alós // Psychooncology. - 2014. - Vol. 23 (8). P. 953-955.

3. Отрощенко Н. П. Особливості нециркулярних депресій у онкологічних хворих / Н. П. Отрощенко, вторна психотравматизація (феномен «поділу життя», 100 \% проти 64,4 \% та 100 \% проти 66,7%), схильність до формування співзалежних стосунків (феномен «індукції», 14,1 \% проти 21,9 \% та 11,8 \% проти 22,2 \%), збільшення напруженості психологічних механізмів захисту для досягнення психічного балансу (феномени «децентралізації», 16,7 \% проти 24,0 \% та 19,6 \% проти 28,6 \%; «екстерналізації», 17,9 \% проти 26,0 \% та 17,6 \% проти 30,2 \%).

Висновки. Структура клініко-психологічних феноменів у опитуваних обох статей була подібною: домінували феномени «поділу життя», «нового початку» та "сортера», менш представленими були феномени «маятника» та «екстерналізації», «децентралізації» та «індукції». Гендерні відмінності полягали у тому, що жінки були більш схильними до більшої вибірковості у сприйнятті психотравмуючої інформації, змін у психоемоційному стані на фоні онкологічного захворювання, формування співзалежних стосунків, тоді як для чоловіків притаманним було застосування психологічних механізмів захисту, спрямованих на винесення джерела внутрішньої напруги назовні.

Прогресування онкологічного захворювання супроводжувалося зростанням психічного напруження, песимізму щодо прогнозів лікування, підвищенням вибірковості щодо сприйняття психотравмуючої інформації, формування міжособистісних стосунків з проявами співзалежності, збільшенням напруженості психологічних механізмів захисту. Відмінності у психологічному стані хворих, обумовлені статтю та етапом перебігу онкологічного захворювання [15], мають бути враховані при розробці заходів медико-психологічної допомоги та реалізовані у диференційованому підході імплементації психологічних інтервенцій.

Перспективи подальших досліджень полягають у вивченні особливостей прояву клінікопсихологічних феноменів в залежності від нозології, стадії перебігу онкологічного захворювання, сімейного статусу.

І. П. Отрощенко, П. А. Отрощенко // Психічне здоров'я. 2015. - № 1 (46). - C. 20-24.

4. Anxiety and depression, cognitive coping strategies, and health locus of control in patients with digestive system cancer / M. Kulpa, M. Kosowicz, B. J. Stypula-Ciuba, D. Kazalska // Prz. Gastroenterol. - 2014. - Vol. 9 (6). - P. 329-335.

5. Self-reported depression and perceived financial burden among long-term rectal cancer survivors / Y. Chongpison, M. C. Hornbrook, R. B. Harris [et al.] // Psychooncology. - 2016. - Vol. 25 (11). - P. 1350-1356. 
Огляди літератури, оригінальні дослідження, погляд на

6. Методологічні підходи до вивчення якості життя в гематологічних дослідженнях / І. В. Жулкевич, С. І. Сміян, М. Є. Гаврилюк, [та ін.] // Вісник наукових досліджень. - 2000. - № 3. - С. 16-23.

7. Psycho-Oncology / J. C. Holland, W. S. Breitbart, P. B. Jacobsen [et al.] / ed. Third Edition. - Oxford University press, 2015. $-772 \mathrm{p}$.

8. Перспективи застосування в онкології ліпосомальної форми доксорубіцину - Ліподокс / І. В. Жулкевич, Г. І. Максим'як, Ю. В. Чишкевич [та ін.] // Вісник наукових досліджень. - 2007. - № 3 (48). - С. 7-11.

9. Home-based mindfulness therapy for lung cancer symptom management: a randomized feasibility trial / R. H. Lehto, G. Wyatt, A. Sikorskii [et al.] // Psychooncology. - 2015. - Vol. 24 (9). - P. 1208-1212.

10. Results of a psychooncological group intervention in male cancer patients aged 60 years or older / G. Schneider, B. Kropff, M. Unrath [et al.] // Z. Psychosom. Med. Psychother. - 2016. - Vol. 62 (4). - P. 336-352.

11. Web-based cognitive training for breast cancer sur-

\section{REFERENCES}

1. Bilobryvka, R.I. (2013). Svidomist mizh zhyttiam ta smertiu. Fenomenolohichnyi ta hnoseolohichnyi aspekt [Consciousness between life and death: phenomenological and epistemological aspects]. Acta Medica Leopoliensia, 19, 4, 56-61 [in Ukrainian].

2. García-Torres, F., \& Alós, F.J. (2014). Anxiety in common situations of everyday life in breast cancer survivors. Psychooncology, 23 (8), 953-955.

3. Otroshchenko, N.P., Otroshchenko, I.P., \& Otroshchenko, P.A. (2015). Osoblyvosti netsyrkuliarnykh depresii u onkolohichnykh khvorykh [Specification of non circular depression patients with cancer]. Psykhichne zdorovia Mental Health, 1 (46), 20-24.

4. Kulpa, M.M., Kosowicz, B., Stypula-Ciuba J., \& Kazalska, D. (2014). Anxiety and depression, cognitive coping strategies, and health locus of control in patients with digestive system cancer. Prz. Gastroenterol., 9 (6), 329-335.

5. Chongpison, Y., Hornbrook, M.C., Harris, R.B., Herrinton, L.J., Gerald, J.K., Grant, M., ..., \& Krouse, R.S. (2016). Self-reported depression and perceived financial burden among long-term rectal cancer survivors. Psychooncology, 25 (11), 1350-1356.

6. Zhulkevych, I.V., Smiian, S.I., Havrylyuk, M.Ye., Kmita, H.H., \& Kramar, L.T. (2000). Metodolohichni pidkhody do vyvchennia yakosti zhyttia $v$ hematolohichnykh doslidzhenniakh [Methodological approaches to the study of quality of life in hematological research]. Visnyk naukovykh doslidzhen - Bulletin of Scientific Researches, 3, 16-23 [in Ukrainian].

7. Holland, J.C., Breitbart, W.S., Jacobsen, P.B., Loscalzo, M.J., McCorkle, R., \& Butow, P.N. (Eds.). (2015). PsychoOncology. Third Edition. Oxford University press.

8. Zhulkevych, I.V., Maksymiak, H.I., Chyshkevych, Yu.V., Zhylchuk, V.Ye., \& Sabala, P.H. (2007). Perspektyvy zastosuvannia $v$ onkolohii liposomalnoi formy doksorubitsynu Lipodoks [Prospects of application of doxorubicin-liposomal form oncology - Lipodox]. Visnyk naukovykh doslidzhen - Bulletin of Scientific Researches, 3 (48), 7-11 [in Ukrainian]. облему, випадок з практики, короткі повідомлення vivors with cognitive complaints-a randomized controlled trial / M. F. Damholdt, M. Mehlsen, M. S. O'Toole [et al.] // Psychooncology. - 2016. - Vol. 25 (11). - P. 1293-1300.

12. Psychological intervention targeting distress for cancer patients: a meta-analytic study investigating uptake and adherence / R. Brebach, L. Sharpe, D. S. Costa [et al.] // Psychooncology. - 2016. - Vol. 25 (8). - P. 882-890.

13. Жулкевич І. В. Вікова динаміка змін стану мінеральної щільності кісткової тканини у хворих на хронічну лімфоїдну лейкемію / І. В. Жулкевич, Р. Й. Вибирана, К. В. Баранніков // Вісник наукових досліджень. -2013. № 1. - С. 47-50.

14. Мухаровська І. Р. Клініко-психологічні феномени у онкологічній практиці на різних етапах лікувального процесу / І. Р. Мухаровська // Здобутки клінічної і експериментальної медицини. - 2016. - № 4. - С. 74-77.

15. Вибирана_Р. Й. Фактори формування остеопенічного синдрому в чоловіків, хворих на хронічну лімфоїдну лейкемію / Р. Й. Вибирана, І.В.Жулкевич // Вісник наукових досліджень. - 2013. - № 3. - С. 60-64.

9. Lehto, R.H., Wyatt, G., Sikorskii, A., Tesnjak, I., \& Kaufman, V.H. (2015). Home-based mindfulness therapy for lung cancer symptom management: a randomized feasibility trial. Psychooncology, 24 (9), 1208-1212.

10. Schneider, G., Kropff, B., Unrath, M., Floeth, S., Semjonow, A., \& Doering, S. (2016). Results of a psychooncological group intervention in male cancer patients aged 60 years or older. Z. Psychosom. Med. Psychother, 62 (4), 336-352.

11. Damholdt, M.F., Mehlsen, M., O'Toole, M.S., Andreasen, R.K., Pedersen, A.D., \& Zachariae, R. (2016). Webbased cognitive training for breast cancer survivors with cognitive complaints-a randomized controlled trial. Psychooncology, 25 (11), 1293-1300.

12. Brebach, R., Sharpe, L., Costa, D.S., Rhodes, P., \& Butow, P. (2016). Psychological intervention targeting distress for cancer patients: a meta-analytic study investigating uptake and adherence. Psychooncology, 25 (8), 882890.

13. Zhulkevych, I.V., Vybyrana, R.Y., \& Barannikov, K.V. (2013). Vikova dynamika zmin stanu mineralnoi shchilnosti kistkovoi tkanyny u khvorykh na khronichnu limfoidnu leikemiiu [Age dynamics of bone mineral density in patients with chronic limphoid leukemia]. Visnyk naukovykh doslidzhen - Bulletin of Scientific Researches, 1, 47-50 [in Ukrainian].

14. Mukharovska, I.R. (2016). Kliniko-psykholohichni fenomeny u onkolohichnii praktytsi na riznykh etapakh likuvalnoho protsesu [The psychological phenomenon in oncology practice at different stages of treatment]. Zdobutky klinichnoi i eksperymentalnoi medytsyny - Achievements of Clinical and Experimental Medicine, 4, 74-77 [in Ukrainian].

15. Vybyrana, R.Y., \& Zhulkevych, I.V. (2013). Faktory formuvannia osteopenichnoho syndromu $v$ cholovikiv, khvorykh na khronichnu limfoidnu leikemiiu [Factors of osteopenic syndrome in men, patients with chronic limphoid leukemia]. Visnyk naukovykh doslidzhen - Bulletin of Scientific Researches, 3, 60-64 [in Ukrainian]. 


\title{
Огляди літератури, оригінальні дослідження, погляд на проблему, випадок з практики, короткі повідомлення ГЕНДЕРНЫЕ ОСОБЕННОСТИ ПРОЯВЛЕНИЯ КЛИНИКО-ПСИХОЛОГИЧЕСКИХ ФЕНОМЕНОВ У ОНКОЛОГИЧЕСКИХ БОЛЬНЫХ
}

\section{○Т. Г. Кривонос ${ }^{1}$ И. В. Жулкевич ${ }^{2}$}

\author{
${ }^{1}$ Винницкий национальный медицинский университет имени Н. И. Пирогова \\ ${ }^{2}$ Тернопольский национальный медицинский университет имени И. Я. Горбачевського МОЗ Украины
}

\begin{abstract}
РЕзЮМЕ. Онкологическое заболевание вызывает значительные сдвиги в психическом функционировании пациентов, проявляется как в нозологических психических реакциях и феноменах, так и в клинически выраженных психических расстройствах.

Цель - изучить особенности проявления клинико-психологических феноменов у онкологических пациентов в зависимости от пола.

Материал и методы. На основе информированного согласия в специализированных медицинских заведениях г. Винница, предоставляющих онкологическую помощь, было обследовано 286 онкологических пациентов, в том числе 174 женщины (ГЖ) и 114 мужчин (ГМ). Больных обследовали на различных этапах течения онкопатологии, а именно, при первом столкновении с заболеванием - 78 женщин и 51 мужчина, и при возвращении болезни - 96 лиц женского и 63 - мужского пола.

Результаты. Структура клинико-психологических феноменов у мужчин и женщин была схожей и распределялась следующим образом: феномен «разделения жизни» (80,5% в ГЖ и 81,6 \% в ГМ), «нового начала» (соответственно 79,3 \% и 78,1 \%), «сортера» (69,5 \% и 60,5 \%), «маятника» (39,1 \% и 33,3 \%), «экстернализации» (22,4 \% и 24,6 \%), «децентрализации» (20,7 \% и 24,6 \%) и «индукции» (18,4 \% и 17,5 \%). У женщин выявлена склонность к большей избирательности в восприятии психотравмирующей информации, изменений в психоэмоциональном состоянии в связи с онкологическим заболеванием, формирование созависимых отношений, тогда как для мужчин характерно было применение психологических механизмов защиты, направленных на вынесение источника внутреннего напряжения наружу.

Прогрессирование онкологического заболевания вызывало рост психического напряжения, пессимизма относительно прогнозов лечения, повышение селективности в восприятии информации, деформации межличностных связей, увеличение напряженности психологических механизмов защиты.

Выводы. Изучение клинико-психологических феноменов у онкологических пациентов имеет важное значение для организации мероприятий медико-психологической помощи. Различия в психологическом состоянии больных, возникающие на разных этапах развития болезни и в зависимости от пола, определяют основу для дифференцирования медико-психологических мероприятий.
\end{abstract}

КЛЮчЕВЫЕ СЛОВА: клинико-психологические феномены; онкологические пациенты; гендер; психологическая помощь; психоонкология.

\section{GENDER FEATURES OF CLINICAL-PSYCHOLOGICAL PHENOMENA IN CANCER PATIENTS}

\author{
${ }^{1}$ M. Pyrohov Vinnytsia National Medical University \\ 2. Horbachevsky Ternopil National Medical University
}

SUMMARY. Cancer causes significant shifts in the mental functioning of patients, manifesting as reactions and phenomena, as well as clinically pronounced mental disorders.

The aim of the study - to learn the peculiarities of the manifestation of clinical and psychological phenomena in cancer patients depending on gender.

Material and Methods. On the informed consent at specialized medical cancer institutions in Vinnytsia, 286 cancer patients were examined: 174 women (GW) and 114 men (GM). The patients were studied at different stages of the oncopathology, namely, at the first contact with the disease -78 women and 51 men, and after the return of the disease 96 women and 63 men.

Results. The structure of clinical-psychological phenomena in men and women was similar and distributed as follows: the phenomenon of "life gap" ( $80.5 \%$ in GW and $81.6 \%$ in GM), "new beginning" (79.3\% and 78, respectively). $1 \%$ ), "sorters" (69.5\% and $60.5 \%$ ), "pendulum" (39.1 \% and $33.3 \%$ ), "externalization" (22.4 \% and $24.6 \%$ ), "decentralization" (20.7 \% and $24.6 \%$ ) and "induction" (18.4 \% and $17.5 \%$ ). Women showed a tendency to be more selective in the perception of psychotraumatic information, changes in psycho-emotional state in connection with cancer, formation of dependent relationships, while for men was typical use psychological defense mechanisms aimed to externalized psychological tension.

The progression of cancer led to increasing psychological tension, pessimism about prognoses, increased selectivity in the perception of information, deformation of interpersonal relations, and increasing intensity of psychological defense mechanisms.

Conclusions. The study of clinical-psychological phenomena in cancer patients is important for the organization of medical-psychological help. Differences in the psychological state of patients, occurring at different stages of the disease and depending on the gender, determine the basis for differentiation of medical-psychological measures.

KEY WORDS: clinical-psychological phenomena; cancer patients; gender; psychological help; psycho-oncology. 